\title{
Analysis of meat consumption on the market of the Kursk region
}

\author{
Svetlana Mikhailova ${ }^{1}$, Ljubov Chernysheva ${ }^{1}$, and Tatyana Ilyushina $^{2}$ \\ ${ }^{1}$ Associate professor, South-Western State University, 305004, 50 Let Oktyabrya str., 94, Kursk, Russia \\ ${ }^{2}$ Associate professor, M. Kozybayev North Kazakhstan University, north Kazakhstan region, Petropavlovsk, Abaya str., 9 , \\ Kazakhstan
}

\begin{abstract}
The regional meat market is part of the all-Russian meat market and part of the agricultural and food markets. A market forecast is a scientific foresight of the prospects for the development of demand, supply and prices. Its main role is determined by the large volumes of manufacture and consumption of this group, as well as the importance of meat and meat products as the main sources of animal proteins in the human diet. The structure of meat consumption in Russia and in the Kursk region until 2020 was investigated. The consumption of basic food in thousand tons per capita per year was given, the provisions characterizing the meat market of the Kursk region were determined. The conjuncture of the meat market of the Kursk region is characterized by the ratio of supply and demand for meat and meat products, as well as by the level and ratio of prices. A market analysis of the meat market of the Kursk region was carried out, taking into account external factors (level and structure of income, national production, imports, etc.). The supply and demand curves of the meat market were obtained for the last 5 years. The interrelationship of demand for a product and its determinants is reflected by the general demand function and is presented in the form of a multiple regression model. The regressive addiction of the volume of demand was made up using the MathCADProfessional package. The solution to the system of linear equations is presented in matrix form. The vector of estimates of the regressive model was obtained and an additive function was compiled on the basis of this vector. The forecast of the demand for meat in the Kursk region was obtained using neural networks (NN). The configured network was used for forecasting using the Neural Network Emulator softwares llike magnm, calciumesium, potassiu, zinc, copper, molybdenum, sodium and chlorine, increased.
\end{abstract}

\section{Introduction}

The dynamics of meat consumption in Russia differs from trends in other significant markets. The level of meat consumption is based on an estimate of the growth of incomes of the population. In 2020, meat consumption in Russia (in dressed weight) reached a record of 77 kilograms per capita. A meat consumption is stabilizing in Russia and meat production is growing.

The demand for products is determined by the purchasing power of the population and other subjective factors. The regional meat market is a system in which good exchange between producers (sellers) and customers. The research of market conjuncture involves the study of its development in the near future to determine what measures should be taken in order to better satisfy the demand of the population for goods, to more rationally use the opportunity to increase exports while enriching its own market and ensuring the food security of the region. Constant study and forecasting of the market conjuncture is a prerequisite for the successful operation of the region.

\section{Methods}

The research methods of the regional market were used in the works of such scientists as A. Belousov, V. Oreshin, Y. Vertakova, E. Kuzbozhev.

The meat consumption is stabilizing in Russia and meat production is growing. The conjuncture of the meat market of the Kursk region is characterized by the ratio of supply and demand for meat and meat products, as well as by the level and ratio of prices $[3,6,7,8,12,15]$. The regional meat market is a system in which good exchange between producers (sellers) and customers. The target benchmark for the development of the meat complex can be the expected volume of demand for the industry's products. The research of market conjuncture involves the study of its development in the near future to determine what measures should be taken in order to better satisfy the demand of the population for goods, to more rationally

* Corresponding author: 
use the opportunity to increase exports while enriching its own market and ensuring the food security of the region $[13,15,16]$.

The regional meat market is part of the all-Russian meat market and part of the agricultural and food markets. Its main role is determined by the large volumes of manufacture and consumption of this group, as well as the importance of meat and meat products as the main sources of animal proteins in the human diet $[1,2,3]$. In the Kursk region, the supply of meat products from commodity producers is four times higher than consumption. The target benchmark for the development of the meat complex can be the expected volume of demand for the industry's products. Constant study and forecasting of the market conjuncture is a prerequisite for the successful operation of the region $[1,3,7,8,14,15]$.

In this regard, the conjuncture of the meat market of the Kursk region is characterized by the ratio of supply and demand for meat and meat products, as well as by the level and ratio of prices $[3,6,7,8,12,16]$. The research of market conjuncture involves the study of its development in the near future to determine what measures should be taken in order to better satisfy the demand of the population for goods, to more rationally use the opportunity to increase exports while enriching its own market and ensuring the food security of the region. $[3,6,7,8,11,16]$. Constant study and forecasting of the market conjuncture is a prerequisite for the successful operation of the region $[1,3,7,8,11,13,14]$.

The target benchmark for the development of the meat complex can be the expected volume of demand for the industry's products.

The interrelationship of demand for a product and its determinants is reflected by the general demand function and is presented in the form of a multiple regression model:

$\mathrm{QDx}=\mathrm{f}(\mathrm{Px}, \mathrm{Py}, \mathrm{I}, \mathrm{Tx}$, Inx, Pasx, q $)$,

where QDx is the volume of demand for meat and meat products per unit of time;

Px - average product price, in rubles;

$\mathrm{Py}$, is the price of a substitute product (fish), in rubles;

I - the average income of the customer, in rubles. per year; year;

Tx is the average meat consumption per person, $\mathrm{kg}$ per

Inx - consumer price index, at times;

Pasx - structure of consumption expenses on products, in $\%$;

$\mathrm{q}$ is the number of consumers of products.

The primary statistical information was brought to a level where it is possible to build a regressive addiction of the volume of demand on the above-mentioned factorsigns using the MathCADProfessional package [9,10].

The forecast of the demand for meat in the Kursk region was obtained using neural networks $(\mathrm{NN})$, since $\mathrm{NN}$ technology is a rather flexible tool for predicting various indicators and can be used to forecast demand $[2,3,8,10,11]$.

The neural network tuning process was carried out with repeated running of the training examples until the error value decreased to acceptable limits. The configured network was used for forecasting using the Neural Network Emulator program.

The neural network was trained under the following conditions and restrictions (neural network configuration):

- sigmoid parameter: 0.5 (used to provide nonlinear data conversion);

- number of entrances: 7;

- number of hidden layers: 1;

- layer 1 - number of neurons: 6;

- number of outputs: 1 ;

- learning speed: 0.1 ;

- moment: 0.9;

- criteria for stopping learning: 10,000 epochs have passed,

- using the test set as a validation one, that is, training was stoped with the appearance of a message as soon as the error on the test set begins to increase.

\section{Results and discussion}

The dynamics of meat consumption in Russia differs from trends in other significant markets. The level of meat consumption is based on an estimate of the growth of incomes of the population. In 2020, the average annual consumption of animal proteins in our country was 25.1 kilograms per capita, which is one kilogram more than in 2019. In 2020, meat consumption in Russia (in dressed weight) reached a record of 77 kilograms per capita. On average, the consumption of meat in the world is 43 kilograms per person per year, and, according to the UN, in rich countries it is 83 kilograms [1].

To construct the supply and demand curves, the following data were required, presented in table 1 .

Table 1. Indicators characterizing the meat market of the Kursk region

\begin{tabular}{|c|c|c|c|c|c|}
\hline \multirow[t]{2}{*}{$\begin{array}{l}\text { Types of } \\
\text { products }\end{array}$} & \multicolumn{5}{|c|}{$\begin{array}{l}\text { Average consumer prices rubles. per kg. by } \\
\text { years }\end{array}$} \\
\hline & 2015 & 2017 & 2018 & 2019 & 2020 \\
\hline Beef & $\begin{array}{c}265,5 \\
6\end{array}$ & 272,4 & 295,1 & $\begin{array}{c}274,4 \\
4\end{array}$ & 276,9 \\
\hline Pork & $\begin{array}{c}230,7 \\
1\end{array}$ & 219,5 & 245.9 & 228,7 & 230,9 \\
\hline $\begin{array}{c}\text { Chicken's } \\
\text { meat }\end{array}$ & 109,3 & 98,79 & 134,7 & 124,8 & 125,9 \\
\hline \multicolumn{6}{|c|}{ Production volumes (in dressed weight), thousand tons } \\
\hline $\begin{array}{c}\text { Total } \\
\text { categories } \\
\text { in farms }\end{array}$ & 338,7 & 406,0 & 416,0 & 424,2 & 530,3 \\
\hline \multicolumn{6}{|c|}{ Volume of meat realization, thousand tons } \\
\hline & 399.4 & 493,8 & 508,4 & 509,0 & 530,0 \\
\hline
\end{tabular}
2. 


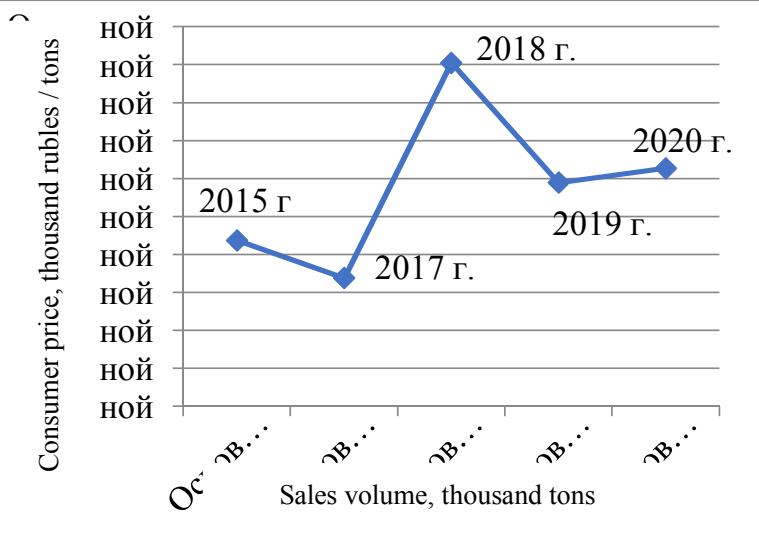

Fig 1. Demand curve

The demand curve has been changing since 2015, but sales volumes are constantly growing and do not depend on consumer prices. An increase in demand with an increase in prices is observed in the case of indispensability of products, and this happens in the meat market. In this case, the elasticity of demand is above zero.

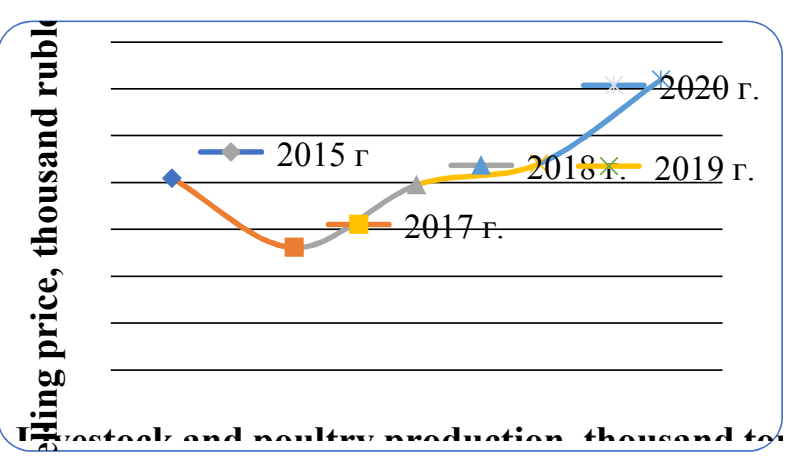

Fig 2. Supply curve

The supply curve since 2017 has been "classic", that is, a positive slope. The supply and demand curves do not intersect.

Let's Form the elements of a series of retrospective data on the volume of demand obtained by multiplying the population of the Kursk region by the actual consumption of meat and meat products on average per person per year. The retrospective period is $2005-2020$ [5, 6, 7, 8].

Factor signs affecting demand will be reduced to a comparable form (Px, Py, I) and are given in 2020 prices.

This procedure requires data of consumer price indices (CPI) (Table 2).

Table 2. Consumer price indices for the retrospective period in the Kursk region

\begin{tabular}{|c|c|c|c|c|c|}
\hline Year & $\mathbf{2 0 1 5}$ & $\mathbf{2 0 1 7}$ & $\mathbf{2 0 1 8}$ & $\mathbf{2 0 1 9}$ & $\mathbf{2 0 2 0}$ \\
\hline CPI & 4,6 & 0,9 & 1,9 & 4,3 & 4,9 \\
\hline
\end{tabular}

Having retrospective data about indices and cost indicators, we calculate the indicators taking into account the consumer price index (Table 3 ).

The primary statistical information was brought to a level where it is possible to build a regressive addiction of the volume of demand on the above-mentioned factorsigns using the MathCADProfessional package.
Table 3. The given indicators for the retrospective period 2005 $-2020$

\begin{tabular}{|c|c|c|c|c|c|c|c|c|}
\hline Year & QDx & Px & Py & I & Tx & Inx & Pasx & $\mathbf{q}$ \\
\hline 2005 & 251356 & 72.5 & 45,5 & 15106 & 47 & 1,2 & 11,0 & 5348,0 \\
\hline 2013 & 410400 & 125,3 & 89,3 & 19566 & 51 & 1,5 & 8,5 & 8000,0 \\
\hline 2014 & 497250 & 199,8 & 91,6 & 2106 & 58,5 & 3,22 & 9 & 8500,0 \\
\hline 2015 & 531424 & 201,8 & 100,7 & 25330 & 59 & 4,6 & 9 & 9002,0 \\
\hline 2017 & 690525 & 196,8 & 124,4 & 26111 & 75 & 0,9 & 8,2 & 9207,7 \\
\hline 2018 & 685343 & 225,2 & 128,8 & 27275 & 75 & 1,9 & 8,2 & 9077,4 \\
\hline 2019 & 731952 & 209,4 & 130,1 & 29246 & 78 & 4,3 & 8,5 & 9384,0 \\
\hline 2020 & 810652 & 211,3 & 135,5 & 35224 & 82 & 4,9 & 9,4 & 9586,0 \\
\hline
\end{tabular}

As a result of data processing by methods of regression analysis, the following results were obtained:

- multiple correlation coefficient $\mathrm{R}=0.893$, determination coefficient $\mathrm{R} 2=0.782$;

- the significance of the coefficients of the regression equation was checked using the Student's test (tstatistics). The following t-test values were obtained: b114.76; b2-14.77; b3-10.28; b4-14.56; b5-14.78; b6-14.66; b7-13.56.

We represent the solution of the system of linear equations in matrix form:

$$
\begin{aligned}
Y & =\left\{\begin{array}{c}
251356 \\
410400 \\
497250 \\
531424,8 \\
690525 \\
685343,7 \\
731952 \\
810652
\end{array}\right\} X \\
& =\left\{\begin{array}{llllllll}
1 & 72,5 & 45,5 & 15106 & 47,0 & 1,2 & 11 & 5348 \\
1 & 125,3 & 89,3 & 19566 & 51,3 & 1,5 & 8,5 & 8000 \\
1 & 199,0 & 91,6 & 21060 & 68,5 & 3,2 & 9,0 & 8500 \\
1 & 201,9 & 100,7 & 25330 & 59,0 & 4,6 & 9,0 & 9002 \\
1 & 196,8 & 124,4 & 26111 & 75,0 & 0,9 & 8,2 & 9207 \\
1 & 225,2 & 128,8 & 27275 & 70,1 & 1,9 & 8,2 & 9207 \\
1 & 209,5 & 130,2 & 29247 & 78,0 & 4,3 & 8,5 & 9384 \\
1 & 211,3 & 135,5 & 35225 & 82,0 & 4,9 & 9,4 & 9586
\end{array}\right.
\end{aligned}
$$

The formula for calculating the vector of regression coefficients in the vector-matrix notation has the form [9, p. 311]:

$$
b=\left(X^{T} \cdot X\right)^{-1} X^{T} \cdot y
$$

We obtain the vectors of estimates of the regression model and, based on the obtained vector of estimates of the regression model, we compose an additive function: $y=-7,563 \cdot 10^{4}+7,593 \cdot x_{1}-10,541 \cdot x_{2}+0,021 \cdot x_{3}+1.336 \cdot 10^{3} \cdot x_{4}(3)$ $-20.637 \cdot x_{5}+70.261 \cdot x_{6}+55.799 \cdot x_{7}$

The next step of the study will be obtaining calculated values for the function and the relative error, which we will summarize in Table 4.

The relative error $\mathrm{S}$ is determined by the next formula:

$$
S=\frac{y_{\text {actual }}-y_{\text {settlement }}}{y_{\text {actual }}} \cdot 100 \%
$$

where $\mathrm{y}_{\text {actual }}$ is the actual value of demand for products, $\mathrm{y}_{\text {settlement }}$ - is calculated value. 
Table 4. Table of actual and calculated values of the function and calculation errors

\begin{tabular}{|c|c|c|c|}
\hline Year & $\begin{array}{c}\text { Actual demand } \\
\text { for products } \\
\text { (tons) }\end{array}$ & $\begin{array}{c}\text { Estimated } \\
\text { demand for } \\
\text { products (tons) }\end{array}$ & $\begin{array}{c}\text { Calculation } \\
\text { error, \% }\end{array}$ \\
\hline 2005 & 251356 & 268574.89 & 6,8504 \\
\hline 2013 & 410400 & 42731.76 & 4,1208 \\
\hline 2014 & 497250 & 523119.92 & 5,2026 \\
\hline 2015 & 531424,8 & 564399,17 & 6,2049 \\
\hline 2017 & 690525 & 737490,36 & 6,8014 \\
\hline 2018 & 6853437 & 707603,66 & 7.3317 \\
\hline 2019 & 731952 & 755725,8 & 3,2480 \\
\hline 2020 & 810652 & 859990,71 & 6.0863 \\
\hline & & Average error & 5.73308 \\
\hline
\end{tabular}

The volume of the array of values of the input variables was limited to 5 years (Table 6). The forecast values for the next 2 years $(2021,2022)$ will be calculated using the Statistica 6.0 package. The real values of the input indicators were entered into the program and the predicted values of the QDx variable were obtained:

Q2021=860321 tons; Q2022=883254 tons.

In the course of training, the following was achieved: the value of the average error of the training sample is 0.0001204 , the test sample is 0.0003134 . The maximum error of the training and test sample was 0.00108 and 0.00106 , respectively.

\section{Conclusions}

According to the data obtained, we can conclude that the demand for meat and meat products is growing in the Kursk region, the market is developing, and business activity is quite high.

This is a positive trend despite the fact that solvent demand is unstable. An optimistic forecast of growth in demand for meat in the short term has been obtained.

\section{References}

1. A.G. Belyaev, Statistical Yearbook of the Kursk Region 2020 (2021) Trends in the development of the regional personal market: theory and practice: University book (2016)

2. E. A. Pyanikova, A. E. Kovaleva, A. A. Gorokhov, Problems of identification, quality and competitiveness of consumer goods: University book (2015)

3. O. A. Sukhorukova, S. A. Mikhailova, E. N. Kuzbozhev, Regulation of market conjuncture: monograph (2007)

4. E.N. Kiseleva, O.V. Vlasova, E.B. Konnova, Mmarket of foodstuffs: a textbook for students of higher educational institutions: University textbook (2013)

5. T.G. Morozova, Regional economy: textbook (2015)
6. E. N. Kuzbozhev, Yu. V. Vertakova, Forecasting and planning of socio-economic development of Russia and its regions: monograph (2003)

7. Yu. V. Vertakova, E. V. Sibirskaya, Management of the regional economy: an innovative aspect: monograph (2012)

8. R.J. Hyndman, Y. Khandakar, Automatik time series forecasting: The forecast package for $R$. Journal of Statistical Software. № 26 (3), 17-20 (2008)

9. H. Kantz, T.Schreiber Nonlincar Time Series Analysis. (2004)

10. D Wang., T.H.Yeats, S.Uluisik, J.K. Rose, Fruit softening: revisiting the role of pectin. 4 (23), 302310 (2018)

11. R. Ciriminna, A. Fidalgo, R. Delisi, L. M. Ilharco, Agro Food Ind. HiTech. Pectin production and global market 5 (27), 17-20 (2016)

12. E.A. Borkova, T.N. Kochkin, O.N. Petrushenko, A.E. Kartavchenko, L.V. Vatlina. Analysis of the correlation of the gross regional product and the economic indicators of the region by the method of mathematical regulation (case of Russia) 34 (2019)

13. S. Bodrunov, V.A. Plotnikov. Strategic aspects of national socio-economic development 34 (2019)

14. S. Bodrunov, V.A. Plotnikov. Integration of market and planning tools in economic policy 34 (2019)

15. P.Luo, T.Tanaka. Food Import Dependency and National Food Security. Foods. 10(8),1715, (2021)

16. T.Tkacheva, L.Afanasjeva, L. Goncharenko. The impact of public social expenditures on economic development 29 (2017) 